\title{
African Caribbean Women Writers in Canada: (Un)Disciplining Bodies and Tongues, and Performing Cultural Schizophrenia
}

\section{Myriam Moïse}

\section{CpenEdition}

\section{Journals}

Electronic version

URL: https://journals.openedition.org/ces/5209

DOI: $10.4000 /$ ces.5209

ISSN: 2534-6695

Publisher

SEPC (Société d'études des pays du Commonwealth)

\section{Printed version}

Date of publication: 1 April 2014

Number of pages: 61-70

ISSN: 2270-0633

\section{Electronic reference}

Myriam Moïse, "African Caribbean Women Writers in Canada: (Un)Disciplining Bodies and Tongues, and Performing Cultural Schizophrenia", Commonwealth Essays and Studies [Online], 36.2 | 2014, Online since 15 April 2021, connection on 19 July 2021. URL: http://journals.openedition.org/ces/5209 ; DOI: https://doi.org/10.4000/ces.5209

\section{(c) (i) $\ominus$}

Commonwealth Essays and Studies is licensed under a Licence Creative Commons Attribution - Pas d'Utilisation Commerciale - Pas de Modification 4.0 International. 


\section{African Caribbean Women Writers in Canada: (Un)Disciplining Bodies and Tongues, and Performing Cultural Schizophrenia}

This essay analyses M. NourbeSe Philip's and Olive Senior's un-silencing of the unruly female self. Through the creation of embodied polyphonies, multiple counter-voices, and anti-conformist utterances, these authors re-envision, refashion and turn inside out the old project of colonizing and disciplining indigenous bodies. Simultaneously struggling against the master narratives and feeling intrinsically linked to them, these writers depict the diasporic female self as longing for liberation within and without the word, an allegory of the Deleuzian "schizophrenic manner of living the contradiction."

The female body cannot be universalised nor can it be "understood as an ahistorical, biologically given, acultural [sic] object” (Grosz 18). The body is therefore a product of the tensions between women's lives and the cultural meanings which have marked women's bodily experiences. The black female body must therefore be analysed within a cultural framework capable of rendering the specificity of African female experience. The works of Jamaican Canadian writer Olive Senior and Trinidadian Canadian author M. NourbeSe Philip epitomise feminist Elizabeth Grosz's idea of the body as the cultural product par excellence and as the embodiment of the socio-cultural, the political and the geographical. The difficulty in representing the African Caribbean diasporic female body lies in the fact that it is a marked historicised space of conflicts, as it has been traumatised and dehumanised through the processes of enslavement, colonialism, and neo-colonialism. For a number of African Caribbean female writers (for instance Haitian American writer Edwidge Danticat or Jamaican Canadian writer Nalo Hopkinson), representing the body is in fact a complex project that must articulate their visions of the material body beyond its historical misrepresentations as soundless and invisible. They wish to turn silence into productive utterances, acknowledging their disjointed selves while reshaping them. The transformation of the diasporic African female body into a cultural testimony therefore appears as essential; a body that folds and unfolds itself and "bears in person the marks of a cultural text whose inside has been turned outside" as Hortense Spillers explains in "Mama’s Baby, Papa's Maybe" (67). In fact, some diasporic women writers may strive to reclaim their dismembered selves and reposition their bodies within themselves, thus performing "a turning back upon oneself or even a turning on oneself" in the words of Judith Butler (Psychic Life 3). Others may seek to reshape their discursive selves within what Deleuze calls the "ultimate fold of subjectification" (87). Butler's "figure of turning" (Psychic Life 3) and Deleuze's theory of folding are indeed close as both theorists seek to define a space enabling the production of immaterial forms of subjectivity, one where recovery and freedom can be envisaged.

These theories have been inspired by Foucault's concept of thought as "a process of subjectification" allowing transformation in "a relationship between power relations and confrontation strategies" where "each constitutes for the other a kind of permanent limit, a point of possible reversal" (Foucault 225). Arguing that "power is both external to the subject and the very venue of the subject," (15) Butler agrees with Foucault and Deleuze on the complexities of the process of subjectification. For Deleuze 
however, different subjectivities must emerge through incorporeal realities since for him, "everything is body and corporeal. Everything is a mixture of bodies, and inside the body, interlocking and penetration" (87). These continuous processes of folding/ unfolding, of turning on/back, within/out the bodies/selves throw light on diasporic Caribbean female-authored texts which are constantly unravelling and thus displacing within/out depths and surfaces, within/out closures and openings, within/out real and imagined spaces. Frantz Fanon's dialectic of interchangeable skins and masks, Deleuze and Guattari's schizo-analysis of bodies, Judith Butler's trope of "the turn" as well as Derek Walcott's appraisal of cultural schizophrenia as productive will therefore be highly relevant and referred to throughout this discussion.

What Philip and Senior genuinely share is a need to liberate their tongues to voice their own representations, incorporating their past and present selves, their physical and discursive selves. Both writers allow the body to exist fully in their texts, and choose to make the diasporic Caribbean female body visible, audible and tangible. Their bodily self-representations are multiple and multi-sensorial as they constantly question and unravel notions of corporeality and spirituality, of space and displacement. They depict the fragmented bodies folding over themselves to find individual or collective wholeness, the displaced bodies turning inside out to heal, and the liminal bodies where self and other co-exist. What this paper seeks to demonstrate is how these diasporic female texts reconfigure the space of the schizophrenic bodies, and (re)negotiate the interconnection of past and present, physical and discursive, inner and outer selves.

Allowing the body to free itself from previous constraints, voice its inner nature and display its outer appearance, Philip and Senior develop comparable strategies to depict unruly bodies and tongues in their short fiction, namely Senior's "Zig-Zag" and Philip's "Bad Words." Senior's short story "Zig-Zag" blurs cultural, racial, and class boundaries as it centres on two different young girls: Sadie, a mixed-race middle-class Jamaican girl and Manuela, an African Jamaican working-class girl. Manuela's mother, Desrine, is Sadie's parents' domestic helper, and so the two young protagonists move in and out of social spaces, thus altering their positions as insiders/outsiders depending on the space they occupy. Despite the evident class difference which is conveyed through the protagonists' speech and social behaviour, Sadie identifies herself with the servant's daughter Manuela because of the latter's bodily freedom, and her ability to voice her true self. On the other hand, Muffet, Sadie's elder sister, does not identify with Manuela at all, but rather spites her in order to perform and embrace European "ladyhood," a paradox that the narrative voice constantly draws on.

In NourbeSe Philip's "Bad Words," the young protagonist Miranda also experiences the pressure to be lady-like and, as she moves with her parents from the country to the city, she is increasingly confronted with the reality of the words and actions which are banned in public spaces. As a matter of fact, in these two narratives, young female bodies and tongues are constrained by the demands of patriarchal, social, and (neo)colonial systems which affect the development of their consciousness and discourse. I therefore argue that Senior and Philip have a common agenda which aims to allow the young female bodies to express their true selves so that they may make "a creative use of [their] schizophrenia," and go beyond what Derek Walcott terms "an electric fusion of the old and new," (17) as their works are embodiments of cultural schizophrenia. Creative cultural schizophrenia therefore refers to identities which are not fixed entities, 
but rather function within and without, inside and outside, in public and in private, across the physical and the discursive, the selves and the others. Cultural schizophrenia is a central feature in these fictional narratives where the diasporic female self is often torn between her physical self and her psychical self on the one hand, and between her inner self and the world outside, on the other. In fact, self and other are in perpetual dialogic exchange: "an integrated discourse of self $[\ldots]$ can only be reached after the negotiation of a historically engendered split between the self and its world, between this self and the language it uses" (Gikandi 18).

In Senior's "Zig-Zag," the main protagonist Sadie has to (re)define herself within a triple dimension, as her desires are split between the two versions of herself represented by Muffet and Manuela. On the one hand, she feels she is the other of her same, in the persona of her sister Muffet; and on the other hand, she feels same of her other, in the character of Manuela, the domestic's daughter and her opposite in terms of race and class. Sadie's perception of otherness consequently develops within her inner self as well as within and without her two contradictory doubles, as though she were framed by two opposite entities and were constantly attracted towards or repulsed by them. This triple dimension recalls Fanon's vision of the black "body schema, attacked in several places, collapsed, giving way to an epidermal racial schema. A body which is perceived in triple" (92). Sadie's fragmented consciousness is also reminiscent of Fanon's theory of alienation, and his image of the split body occurs within as well as without the confrontation with the other in the same way as Sadie who has to acknowledge her two others and confront them while dealing with her inner "psychic" self.

While gender is the main category that unites the three girls, a number of factors perpetually disrupt the construction of their female identities. Sadie's attraction towards her sister Muffet and her proper behaviour on the one hand, and her fascination with Manuela and "her rude behaviour" (174) on the other hand, is one of the story's leitmotivs. Sadie's self-construction seems to operate on the margin as she always finds herself confused, and never knows whether "to take up for Manuela or side with Muffet. Usually she did neither, she just pretended she couldn't be bothered to concern herself with any of it" (173). Besides, throughout the story, Sadie yearns to transgress the rules and assert her sexual/undisciplined body. Her body, as a result, is in perpetual tension, it is unstable, multiple. This multiplicity is at odds with the unitary subject which, according to Judith Butler, "is one who enters the conversation the same way as it exists, who fails to put its own epistemological certainties at risk in the encounter with the other, and so stays in place, guards its place, and becomes an emblem for property and territory, refusing self-transformation" (Undoing Gender 228). Far from being unitary subjects, Senior's characters are epitomes of instability and self-transformation. Senior's short story foregrounds the raced and gendered physical body, more precisely through the construction, deconstruction and reconstruction of Sadie's identity with regard to her hair, and the perception she has of her "racially in-between" body (Decaires Narain 48).

Sadie's physical appearance contrasts with that of her sister Muffet. Her dark skin "darker than papa's even" and "coarse and curly" hair (182) are at the origin of her alienation. Learning the difference between "good" skin/hair and "bad" skin/hair according to her community, Sadie comes to the realisation that her physical appearance is a disadvantage in the eyes of her relatives. In addition to her darker skin, Sadie's hair contributes to her inner confusion, as she is constantly devalued by her sister Muffet 
whose hair is easily manageable because it is "fine and straight" (200). Sadie's hair is too thick for her mother to comb, "so they had to get her a big, heavy comb, not like the fine little combs Muffet used, a proper tortoiseshell comb that came with the comb-and-brush set that could sit so prettily on the doily on top of the vanity" (200). Sadie's coarse hair and her mother's difficulty in dealing with it are suggestive of the little girl's boldness and refusal to conform. The story's narrator goes as far as comparing the possible loosening of her wild hair to "letting out a wild beast to run all over the world, scaring clouds and knocking down mountains and overturning rocks and getting tangled in trees and falling into rivers and getting stuck in brambles and heaven knows what else" (200). Through quite an extravagant descending gradatio, the narrator sketches what would happen to Sadie if she were to free her body. Sadie's loosened hair is the synecdoche of her undisciplined body. Her body and hair are not controlled. They are threatening to rebel and set themselves free, but the consequences suggested by the narrative voice are the eventual drowning or imprisonment of the rebellious body, and "heaven knows what else." This hyperbolic prediction further underlines the importance of hair in the story, and the fact that Sadie's physical disciplining must occur through the combing of her hair. However, even when Sadie's hair is cut by her mother, it is a sort of failed castration, as the latter's ultimate attempt to take control of her daughter's body fails when her hair becomes dry "like coconut husk," "like bush," (200) denoting the little girl's persistent wildness. Although her short hair looks like bush, Sadie nevertheless enjoys her haircut, and asserts the boldness of her body and her in-betweenness when it comes to her identification with and difference from both Muffet and Manuela:

She liked the way it made her look wild and different, different from everybody else. Liked the way she could stand in front of the mirror and shake it to make it shimmy. Liked to run her hand through it and feel its waviness. Liked the shape of her head. But Mother Dear prayed for her hair to grow back so it could be controlled by plaits, kept under restraint by ribbons and hairclips. (200-201)

The emphasis on the word "different" through duplication and the accumulation of sentences evoking Sadie's initial enjoyment of her different physical appearance and freedom soon give way to misgivings. The ribbons and hairclips somehow recall the chains and irons to secure physical binding, and through their rejection, Sadie openly defies her mother's desire to restrict and discipline her body. The motherly desire is reminiscent of Deleuze and Guattari's notion of the "desiring machine" as producing subjects and objects. (184). In this passage, Sadie imagines her mother's inner thoughts while the latter is plaiting her hair, and this depiction is evocative of the mother's machine-like desire for social (re)production:

Every daughter of mine is going to turn out properly, Sadie could imagine Mother Dear thinking furiously as, with the hair captured and subdued, rolled into two and pinned up, she could now safely take hold of each section and begin to plait. Every one (plait). Even those (plait) who acted (plait) like they belonged (plait, plait) in the fish vendors' side (plait) of Mo Bay market (plait, plait). (201)

Mother Dear's hair combing progressively turns into a mechanical process through which Sadie's hair and her body/self are "captured," "subdued," and marked through the motherly tracing and dividing of hair, a further evocation of the mother's desire to impose order and discipline on her daughter. As Sadie's mother plaits her hair, her 
gestures are in harmony with her speech, as though she were weaving discourse into her daughter's hair, thus producing a metaphor for the need to inscribe a specific identity on her daughter's body. The repetition of the verb "plait" between brackets denotes a mixture of mimology ${ }^{1}$ and exorcism. The shaping of Sadie's hair becomes synonymous with a conjuration, a mechanical brainwashing, and a desire to control her bodily space at all costs. The parallel with exorcism is all the more significant as Sadie is seen as a "restless spirit" (155) throughout the story, hence her mother's urge to expel the alien other which distances her from the European lady-like behaviour that she should have embraced, as her elder sister Muffet already has.

In Senior's "Zig-Zag," everything seems to be in a process of transformation and uncertainty, and the Creole language often spins around and transforms into standard speech when necessary. Senior's characters therefore appear to journey between tongues and identities, a fact which may be embodied in the title of the story "Zig-Zag," as the Caribbean female protagonists are depicted as "zigzagging," or teetering between cultural spaces. The emergence of a specific (discursive or physical) self is here associated with space, private and public spaces, inside and outside spaces that the protagonists all explore. Yet what is noticeable is the common aspect of the cultural schizophrenia that marks Senior's female protagonists who choose to act out a different self according to familial, social, and racial constraints. Senior's strategy can be summed up as one in which no fixed notion of identity prevails, as there is always a self shaping, unshaping and reshaping within the initial self or within the other self, thus giving birth to an incorporeal self.

In Philip's short story "Bad Words," the central theme is essentially the necessity for the self to recover its language; the split of the self occurs doubly, first with regards to the other, and second, within the inner self. Like Senior's young protagonist Sadie, Philip's main character, Miranda, has to deal with the otherness within herself as well as with the interactions with her different "others" that she envies or with whom she identifies. However, while there is no mention of an active masculine other to be envied in Senior's short story, Philip's protagonist starts her journey by envying one of her masculine counterparts for his liberty of speech and movement. The case of Miranda, however, echoes Sadie's situation, particularly when she has to face the restriction of her physical and discursive freedom after moving with her parents from the country to the city:

Now the forbidden was the usual: forbidden places, especially for girls; forbidden books, forbidden people, forbidden words, forbidden thoughts... [...] For a while, Miranda had envied her new friend - nothing was forbidden him. [...] his ignorance of the forbidden was absolute. As absolute as her envy of him. And she could feel her thin body vibrate with the energy of want - so keen was her desire at times for this state where the forbidden did not matter. (20)

The recurrence of the word "forbidden" emphasises the girl's longing for freedom but also her desire for unbound space and speech. Her yearning, however, acquires an additional dimension through a double-entendre, as Miranda's urge for liberty fuses with her sexual desire, "her envy of him" acting both on her sexual body and on her psychic self. The pun is somewhat reminiscent of the Freudian concept of "penis envy" according

1. Dupriez defines mimology as “an imitation of the human voice or of speech habits, or of a person's pronunciation. Mimologies are produced by voicing or unvoicing consonants; by phonemic lengthening; and by transcription of noises" (283). 
to which the psychoanalyst sees the girl's discovery of sexual difference through "the fact of her castration" (95-6). According to Freud's theory, the girl's smaller clitoris forcibly creates envy towards her male counterpart when she sees his penis: she identifies herself within the "lack" of a phallic organ, as though she had been originally castrated and left with a wound. Here Miranda is pictured as strongly envying her male friend as "nothing was forbidden him," which suggests absolute patriarchal power for, whereas she is restricted, he can go anywhere and speak as he wishes, supposedly because he has phallic privileges. Freud's penis-centred theory of female sexuality was however criticised for its misogynistic assumptions: its election of the male organ as the desired object par excellence, and its depiction of women as inferior beings (Belsey and Moore 5).

In "The Power of Discourse and the Subordination of the Feminine," Luce Irigaray is highly critical of Freud's vision of the feminine "in terms of deficiency or atrophy," and "as the other side of the sex that alone holds a monopoly on value: the male sex. Hence the all-too-well known "penis envy"' (69). From Irigaray's point of view, the female subject needs to assert her "specific sexuality" outside of the Freudian discourse and of phallocentric discourse above all. A woman must therefore "work at 'destroying' the mechanism of discourse," and "try to recover the place of her exploitation by discourse, without allowing herself to be simply reduced to it" (76). Irigaray's envisaged recovery through discourse is echoed in Philip's "Bad Words," as beyond the restriction imposed on her sexual body, it is the limitations imposed on her discursive body that Miranda resents; thus her self-assertion and liberation will have to occur through the power of the word.

Unexpectedly, Miranda's attention soon shifts towards a female character, and what Philip seems to aim at is a displacement of "penis envy" from a masculine to a feminine character, hence moving from envy to admiration. In fact, Miranda forgets about the physical freedom of her male counterpart when she discovers the sassy tongue of her female neighbour, Pomona Adams. Recalling Sadie's constant admiration for Desrine, and her recurrent remarks on her long mouth as a site of contestation, Miranda sees beauty in Pomona's rebellious speech as her "pretty mouth" can produce "powerful words," namely swear words (21-2).

Miranda's development as a character is certainly representative of Philip's wish to author(ise) her female protagonists to "perform the truth of flesh and bad words" (22). In fact, the necessity to control and discipline unruly bodies, which becomes pivotal in Senior's narrative through the synecdoche of hair combing, finds a counterpart in the synecdoche of the tongue in Philip's short story, a recurrent theme in all of her work. In "Bad Words," Miranda's mother wishes to control her improper speech. Miranda's envy of Pomona's physical and verbal freedom is central to the narrative, as the young girl "recognises artistry" (21) when she hears Pomona speak. This admiration is reminiscent of Barbadian American novelist Paule Marshall's vision of her mother and her female friends' ritual chat as poetry in her essay "From the Poets in the Kitchen." In a manner similar to that used in her poetry collection She Tries Her Tongue, Her Silence Softly Breaks, Philip uses prose to draw an intrinsic link between body and speech in "Bad Words" through Miranda's admiration for Pomona's body language.

Something about the way Pomona walked made Miranda suspect that Pomona's words, especially the bad ones, and the way she used them were connected with her body. She used her words like she walked, with a prideful determination that matched her size. (21) 
Pomona's striking physical presence illustrates Jamaican theorist Carolyn Cooper's "Slackness/Culture Dialectic," (143) and her perception of the Jamaican female body as boldly "vulgar" and noisy. "Popular culture, low culture, mass culture, the vulgar discourses of the feminised native body, pronounce the ancient blessings of the word made flesh: noises in the blood; echoes in the bone" (198). Pomona is admired by Miranda precisely because she can perform indiscipline and slackness freely and naturally. When Pomona confronts her neighbour, her outrageous behaviour testifies to her bodily empowerment, causing Miranda to envy her:

Pomona turned her back to her opponent and with two hands flung her skirt up and up over her behind: down, down, and still further down came Pomona's panties, her hands swift and sure with the choreography of pride. "Look, you want to see flesh, this, this is flesh!" And there for all the world who cared to look, and Miranda, was Pomona's fat backside exposed to the sweet morning air as she grabbed a handful of her brown flesh to demonstrate the proof of its existence. (22)

Through this episode, Pomona's body achieves not only hyper-visibility and audibility, it is also made palpable through the grabbing of her own flesh "to demonstrate the proof of its existence." What began as a discursive clash turns into a physical confrontation, as it is through her body that Pomona imposes her word, thus performing "the truth of her flesh and speech":

Proud, and in the brown amplitude of her flesh, unashamed of her size or her words, any of her words, particularly the bad ones that now, after the unmatched challenge of her flesh, issued forth from her round pretty mouth, Pomona threw her words in her neighbour's face and made a stand for truth - the truth of flesh and bad words. (22)

This passage is evocative of Carolyn Cooper's statement in Noises in the Blood. Orality, Gender and the "Vulgar" Body of Jamaican Popular Culture: "The amplitude of the body becomes a figure for the verbal expansiveness that is often the only weapon of the politically powerless; tracings and other forms of verbal abuse are essential armaments in class welfare" (41). More than effecting a connection between the physical and the discursive, in Philip's text, bodies and words interchange and fold into one another, in a sort of chiasmic process signifying the actual material/physical nature of the words and the immaterial/discursive nature of the flesh.

The physicality of the word is central in "Bad Words," as Miranda is always depicted as struggling against the weight of words. The bad words Pomona and her neighbour throw at each other (22) have something solid or tangible about them: "They all had edges - hard edges that hurt somehow as she intentionally and deliberately strained her mouth around them, her tongue paying strict attention to their individual shapes" (16). Language is ambivalent since although words are immaterial, they are nevertheless depicted as visible and palpable. When mastered, swear words in particular are felt to be powerful and even erotic, as shown by the implicit comparison of their mouthing with fellatio. But the same words can also be perceived as harmful when not uttered. Their ambivalence is a source of wonder, as when the narrator depicts Miranda's attraction to her parents' discussion of local politics:

She heard the voices rise and fall, passion and excitement strengthening the rhythms of an already rhythmic language. "Yes, but he not going far enough, England and America still going control the economy." The cadenced voices reflect the trajectory, the rise and fall of empire. The deep bass of her father's voice and her mother's higher softer tones throw back and forth between them words like "politics" and "freedom," pulling a thread 
here, a strand there, trying hard to twist and braid these hard, new words into dreams for their children - a good job in the civil service perhaps, exploring the furthest limits of their world - maybe even a doctor! (24).

Here the spoken and the written intermingle in the description of the parents' "cadenced voices," which can be understood as an allegory of the material rise and fall of the British empire, thus equating "rise" to speaking and "fall" to silencing. The analogy with braiding recalls the plaiting of African hair, and further suggests the materiality of the new language which grows like hair, thus requiring pulling and styling, a vision which echoes Senior's short story. Philip's text is in itself a mixture of words shaping and reshaping while being uttered through multiple sounds and textures, implying that the power of the tongue lies within its capacity to transform the wor(l)d(s): "words, words that they stocked and fired into life, and now would not let die, words that under the lash and caress of their tongues now transformed themselves" (24).

Philip's narrative is trans-sensorial, as shapes and colours, noises and silences constantly interlock, making words and worlds visible, audible and even palpable. Trying her own Creole, this "unruly substance," or this "bastard tongue" (Nettleford 9-10), Philip also acknowledges the ambivalence of the tongue as both a discursive and a sexual tool. At the close of the narrative, the words that Miranda has been testing and performing in secret eventually come out in the sacred public space of the church community, where she chooses to liberate her inner utterances:

Miranda smiled and rushed to embrace the unembraceable, the forbidden: "and your mother's cunt"! [...] she understood badness now and that was what mattered. The words had not stained her mouth - even in this public uttering. The moist, wet, pink space of her mouth had become a tender womb to bad words, any words - mother's cunts, pricks, dicks - the words were embedded deep inside Miranda filling up all the secret places and spaces created by the forbidden. (25-6)

Philip's materiality of language is confirmed here as Miranda experiences the supposedly harmful bad words, which she expected to stain her mouth. The "moist, wet and pink space of her mouth" evokes the forbidden word for the female genital organ she has just uttered. The transgression occurring through language and in her mouth is also compared to "a tender womb to bad words, any words," thereby producing and reproducing the words but above all transforming and asserting the self through words. The ambivalent nature of the word is further emphasised here, as although their "badness" caused her mother's outrage and her father's physical "flogging," the immateriality of the words makes them eternal and unredeemable. However, if Miranda manages to utter bad words, she later has to face a dilemma. Philip's short story closes on a paradox underlining the fact that although Miranda longed for the power of speech, it was not necessarily through badness and rudeness. Miranda's scars at the end of the story appear as a testimony of her discursive defiance, and her mouth has eventually succeeded in becoming "a tender womb" which (re)produces and transforms the bad words into ambivalent words, both good and bad, incorporating her two selves, the inner and the outer.

In Senior's "Zig-Zag," the story also ends in incompleteness through Sadie's final tears and her mother throwing a huge comb at her that the girl catches in the end. The comb can be interpreted as a phallic symbol of the tracing and the dividing imposed on the girl's hair to discipline and shape it, suggesting that the only choice that Sadie has 
left is to conform and accept the law of matriarchy at the service of patriarchy. Sadie's tears indicate her failure to reject conformity and express herself fully while Manuela's folding of the turban into "tinier and tinier squares" (213) towards the close of the story may be interpreted as a metaphor for a renegotiation of her identity through the space within which she can deploy her self. Both Sadie and Manuela long to understand who they are; while zigzagging in between spaces, classes and identities may have been manageable as a child, the end of the story implies that the growing African-Caribbean female subject faces more and more difficulties in navigating between identities. The comb is therefore an instrument for disciplining the body while the tongue is its opposite, the very instrument that allows the body to express itself. Sadie's silence in the end dramatically contrasts with Miranda's discursive liberation, but both protagonists are frustrated by the omnipotence of patriarchal law. While Philip's short story allows for healing and wholeness at the end, Senior's "Zig-Zag" does not seem to foresee an actual recovery. Senior illustrates the impossibility for the child to assert herself in a society that restricts her space, body and speech. On the contrary, Philip author(ise)s Miranda to express her true deviant self discursively and perform her true self through reclamation and re-inscription. The alienated African Caribbean female self aims at liberation within and without the word through the "social interpellation" that Judith Butler theorises:

The social life of the body is produced through an interpellation that is at once linguistic and productive. The way in which that interpellative call continues to call, to take form in a bodily stylistics that, in turn, performs its own social magic constitutes the tacit and corporeal operation of performativity. (Excitable Speech 153)

Philip and Senior both seem to embrace the dialectics of interpellation and performativity as their writing actually stages the possible liberation of the African Caribbean female schizophrenic bodies and the rebirth of their tongues that were historically cut, tortured and silenced. Therefore they aim at unravelling discourse and turning it over so that bodily performance and discursive healing can be envisaged. In these diasporic Caribbean female-authored texts, corporeal and incorporeal liberation often shift in and out of the spaces of defiance, disorder and unruliness since "the schizophrenic is less a question of recovering meaning than of destroying the word":

Triumph may now be reached only through the creation of breath-words (mots-souffles) and howl-words (mots-cris), in which all literal, syllabic, and phonetic values have been replaced by values which are exclusively tonic and not written. (Deleuze and Guattari 88)

Ultimately, the two authors essentially perform the schizophrenic nature of the diasporic female subject whose multiple identities are enhanced as being constantly renegotiated, in such a way that fixity turns into fluidity, and balance gives way to instability, a sort of fluctuating subjectivity which, as African American poet Sonia Sanchez writes, "embraces the unembraceable" and emphasises "the fluid in teeth, the enamel in tongues" (2). 


\section{Works Cited}

Belsey, Catherine, and Jane Moore, eds. The Feminist Reader: Essays in Gender and the Politics of Literary Criticism. London: Macmillan, 1989.

Butler, Judith. Excitable Speech: A Politics of the Performative. New York: Routledge, 1997.

—. The Psychic Life of Power: Theories in Subjection. Stanford: Stanford UP, 1997.

-. Undoing Gender. New York: Routledge, 2004.

Cooper, Carolyn. Noises in the Blood. Orality, Gender and the "Vulgar" Body of Jamaican Popular Culture. London: MacMillan, 1993.

Deleuze, Gilles. The Logic of Sense. Trans. by M. Lester with Ch. Stivale. London: Athlone, 1990. Trans. of La logique du sens. Paris: Editions de Minuit, 1969.

-, and Félix Guattari. A Thousand Plateaus: Capitalism and Schizophrenia. Volume 2. Trans. and Foreword Brian Massumi. London: Continuum, 2004. Trans. of Mille Plateaux. Paris: Editions de Minuit, 1980.

Dupriez, Bernard. A Dictionary of Literary Devices. Gradus A-Z. Trans. Albert W. Hallsall. Toronto: U of Toronto P, 1991. Trans. of Gradus: les procédés littéraires (Dictionnaire). Paris: Union générale d'éditions, 1984.

Irigaray, Luce. "The Power of Discourse and the Subordination of the Feminine." This Sex Which is Not One. Ithaca: Cornell UP, 1985. 68-85.

FanON, Frantz. Black Skin, White Masks. Trans. Richard Philcox. New York: Grove, 2008. Trans. of Peau noire, masques blancs. Paris: Seuil, 1971.

Foucault, Michel. "The Subject and Power." Ed. H. Dreyfus and P. Rabinow. Michel Foucault: Beyond Structuralism and Hermeneutics. Chicago: U of Chicago P, 1982. 208-26.

Freud, Sigmund. "Female Sexuality 1." Psychoanalysis Female and Female Sexuality. Ed. Hendrik M. Ruitenbeek. New Haven: College and UP, 1966. 88-105.

GIKANDI, Simon. Writing in Limbo: Modernism and Caribbean Literature. Ithaca: Cornell UP, 1992.

Grosz, Elizabeth. Volatile Bodies. Toward a Corporeal Feminism. Bloomington: Indiana UP, 1994.

Marshall, Paule. "From the Poets in the Kitchen." Reena and Other Stories. New York: The Feminist P, 1983. 3-12.

Narain Decaires, Denise. Olive Senior. Horndon: Northcote, 2011.

NetTLEFord, Rex. Introduction and Notes for Jamaica Labrish by Louise Bennett. Kingston: Sangster, 1966.

PhiLIP, M. NourbeSe. "Bad Words." The Oxford Book of Stories by Canadian Women in English. Ed. Rosemary Sullivan. Oxford: Oxford UP, 2000. 20-6.

—. She Tries Her Tongue, Her Silence Softly Breaks. London: The Women's P, 1989.

Sanchez, Sonia. Morning Haiku. Boston: Beacon, 2010.

SEnIOR, Olive. Discerner of Hearts and Other Stories. Toronto: McClelland \& Stewart, 1995.

Spillers, Hortense. "Mama's Baby, Papa’s Maybe: An American Grammar Book." Diacritics 17.2 (Summer 1987): 64-81.

Walcotт, Derek. "What the Twilight Says: an Overture." Dream on Monkey Mountain and Other Plays. New York: Farrar, Straus \& Giroux, 1970. 1-40. 